\title{
Trends in Growth of Higher Education in India
}

\author{
Dr. Uma Pujar M.Com., Ph.D. \\ Assistant Professor of Commerce Government First Grade College, Dharwad Karnataka, India.
}

\begin{abstract}
Higher Education is a very important sector for short and long term economic growth and development of human resource which can take responsibility for social, economic and scientific development of the country. India is currently at the stage of demographic transition where population growth is slowing down but, the population of young people entering the labor force continues to expand. This young and large population should be educated for the betterment of the nation. The Government has given the required thrust to the higher education sector by initiating various plans and committees. Government of India aimed to increase Gross enrolment ratio (GER) to $21 \%$ during its Eleventh five year plan (2007-12). To achieve this, the enrolments need to be substantially raised in Universities/Colleges to reach the target by 2011-12.
\end{abstract}

Key words: Higher education, enrolment

\section{Introduction}

Higher Education is very vital to achieve sustainable growth and development of any country. The University Education Commission (1948-49), under the Chairmanship of Dr. S. Radhakrishnan, gave the foundations of the future of Indian Higher Education. The report of the Education Commission (1964-66) under the Chairmanship of Dr. D.S.Kothari symbolized the symbiotic relationship between education and national development. The Central Advisory Board of Education (CABE) Committee was set up in 1921 to enable the Central Government to play an effective role in education, based on consensus among the representatives of the then provincial governments. The National Policy on Education (NPE) 1986 (with modifications undertaken in 1992) states that "the CABE will play a pivotal role in reviewing educational development, determining the changes required to improve the system and monitoring implementation". The Government has also given the required thrust to the sector in its Five Year Plans. During the Eleventh Plan period, India aimed to achieve Gross Enrollment Ratio (GER) to 21\% from 12.3\% at the beginning of the Plan period. Various legislative actions were also taken during this period, including the introduction of the Higher Education and Research Bill, the Educational Tribunal Bill and the Foreign Educational Institutions Bill, to enhance transparency and quality in the sector. This paper attempts to through a light on the status and analyse the trends in Higher education in India during Eleventh plan.

Higher education typically comprises under-graduate, post graduate degrees and pre-doctoral and doctoral programs. According to the National policy on Education (NPE) -86 [1, Part V, p.14], "Higher education provides people with an opportunity to reflect on the critical social, economic, cultural, moral and spiritual issues facing humanity. It contributes to national development through dissemination of specialized knowledge and skills. It is therefore crucial factor for survival. Being at the apex of the educational pyramid, it has also a key role in producing teachers for the education system." This sector can be further classified as technical and non-technical education. Higher education is presumed as education beyond the school level. It has a place at a university or at a college or an institute. While, the UGC is an umbrella regulation which governs any institution imparting degree, the institution carrying out technical education also needs to comply with operational norms specified under All India Council for Technical Education AICTE (for engineering, management studies etc.) and Medical Council of India MCI (for medical) among others.

\section{Objective Of Study}

1. To study the current status of Higher education in India.

2. To analyse the trends in Higher education in India.

\section{Research Methodology}

Research methodology is descriptive and data is based on secondary. For this study data and information has been collected with the help of Books, Magazines, Newspapers, Research Articles, Research Journals, E-Journals, Report on Higher Education in India: Twelfth Five Year Plan (2012-2017) and beyond and ASHE - Annual Status of Higher Education in States and UTs, 2012. 


\section{Higher Education Institutions in India}

The institutions of higher learning in India fall into the following broad categories:

a) Universities: These are established by an Act of Parliament or State Legislature and are of unitary or affiliating type. They are called Central Universities and State Universities respectively.

b) Deemed to be Universities: These institutions are given deemed to be university status by the Central Government on the recommendation of the UGC in terms of Section 3 of the UGC Act. Some of these institutions offer advanced level courses in a particular field or specialization while others award general degrees.

c) Private Universities: These are established by various State governments through their own legislation.

d) Institutes of National Importance: These Institutes are declared as such by the Government of India by an Act of Parliament and are empowered to award degrees. In some cases, such Institutes are also set up by the Government through an Act of State Legislation.

e) Premier Institutes of Management: These are the Institutes that have been set up by the Central Government and are outside the formal university system. They offer Post-Graduate Diploma Programmes which are equivalent to Master's Degree Programmes in area of management.

\section{Trends In Growth Of Higher Education}

The field of study is divided into General and Professional institutions. The streams offered by General Institutions are- Arts, commerce and education. The streams offered by Professional Institutions areEngineering, medical, management, law, other professional and vocation-based courses such as hotel management, architecture, agriculture etc.

Table 1 Trend in Field of study

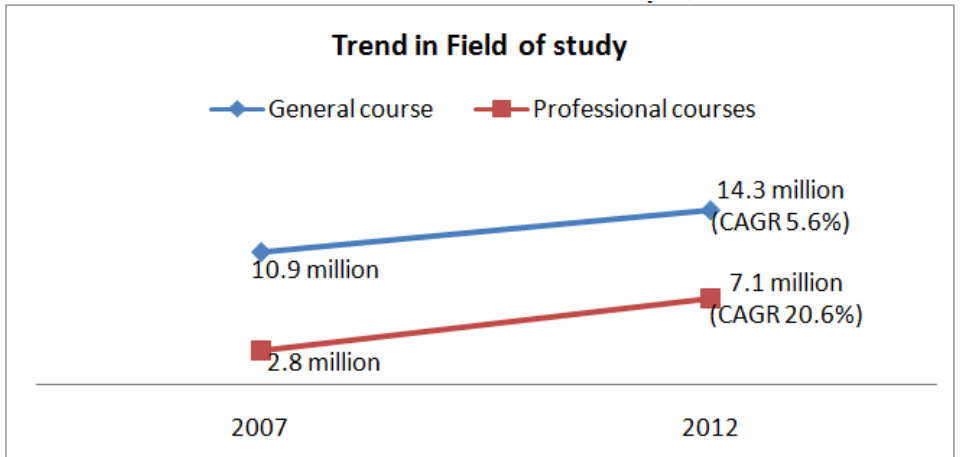

Source: Higher Education in India: Twelfth Five Year Plan (2012-2017) and beyond

Table 1 depicts the trend in field of study. The General courses account for 14.3 million and professional courses accounts for 7.1 million, general course having largest share of enrollment. But, enrollment in professional courses has witnessed a higher growth in the last five years. The CAGR of professional courses was $20.6 \%$ and CAGR of general courses was $14.3 \%$ during 2007-12.

Table 2Comparison with other countries (Number in Millions)

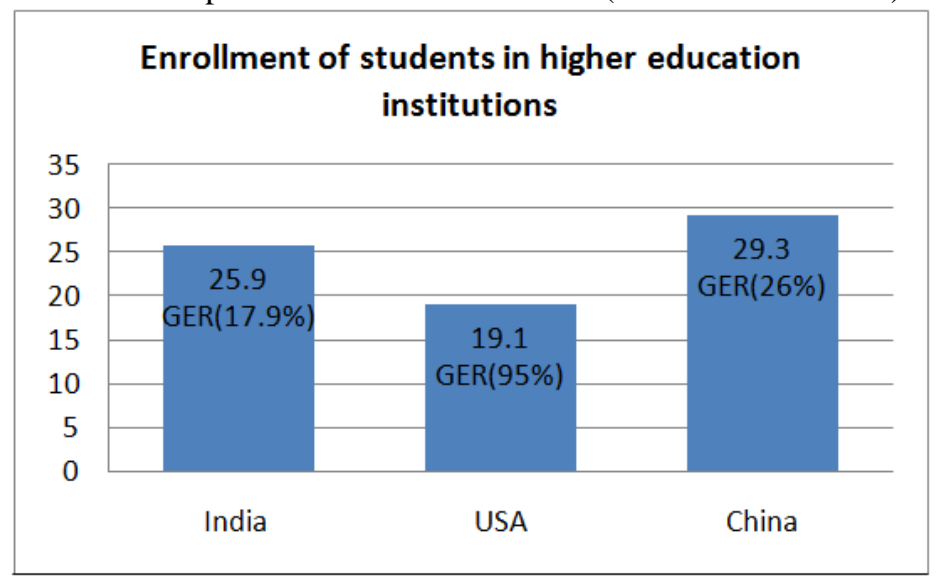

Source: Higher Education in India: Twelfth Five Year Plan (2012-2017) and beyond 
Table 2 shows the comparison between India, USA and China in terms of enrollment of students in higher education institutions. India ranks second in the world in terms of enrollment of students in higher education institutions. India's GER was 17.9\% (2012), China 26\% and USA 95\% in 2010.

Table 3 Enrolment by Faculty wise during the Eleventh Plan (lakh)

\begin{tabular}{|l|r|r|r|r|r|}
\hline \multirow{2}{*}{ Faculty } & \multicolumn{2}{|c|}{$2007-08$} & \multicolumn{2}{c|}{$2011-12$} & \multirow{2}{*}{ Increase } \\
\cline { 2 - 5 } & \multicolumn{1}{|c|}{ Total } & \multicolumn{1}{c|}{$\%$} & \multicolumn{1}{c|}{ Total } & \multicolumn{1}{c|}{$\%$} & \\
\hline Arts & 59.3 & 38.45 & 61.8 & 30.6 & 2.48 \\
\hline Science & 27.37 & 17.75 & 31.3 & 15.5 & 3.9 \\
\hline Commerce \& Management & 24.41 & 15.83 & 29.9 & 14.8 & 5.46 \\
\hline Education & 7.32 & 4.75 & 12 & 5.92 & 4.63 \\
\hline Engineering & 24.14 & 15.65 & 49 & 24.3 & 24.82 \\
\hline Medicine, Nursing \& Pharmacy & 6.86 & 4.45 & 10.9 & 5.41 & 4.05 \\
\hline Agriculture \& Veterinary Science & 1 & 0.65 & 1.21 & 0.6 & 0.21 \\
\hline Law & 2.69 & 1.74 & 3.27 & 1.62 & 0.58 \\
\hline Others & 1.11 & 0.72 & 2.74 & 1.29 & 1.63 \\
\hline Total & 154.2 & 100 & 202 & 100 & 47.79 \\
\hline
\end{tabular}

Source: ASHE - Annual Status of Higher Education in States and UTs, 2012

Table 3 depicts the Enrolment by Faculty wise during Eleventh plan. The total enrolment during 200708 and 2011-12 among the various faculties, the maximum growth in enrolment has been increased in the faculties of engineering (24.82\% increase), followed by commerce and management $(5.46 \%)$ and education (4.63\%). As on 2011-12, the maximum students have been enrolled in faculty of arts (30.6\%) followed by engineering $(24.3 \%)$.

Table 4Student enrolment by gender, Minority community groups And Area wise Gross Attendance Ratio (GAR)

\begin{tabular}{|c|r|r|r|r|r|r|r|r|}
\hline \multirow{2}{*}{ Year } & \multicolumn{2}{|c|}{ Gender } & \multicolumn{4}{c|}{ Minority groups } & \multicolumn{2}{c|}{ Area } \\
\cline { 2 - 11 } & Male & Female & OBC & SC & Muslims & ST & Urban & Rural \\
\hline $1999-2000$ & 12.1 & 8.0 & 7.0 & 5.1 & NA & 6.4 & 21.7 & 5.6 \\
\hline $2004-2005$ & 14.4 & 10.6 & 10.1 & 7.8 & 7.7 & 7.6 & 23.8 & 7.5 \\
\hline $2007-2008$ & 19.0 & 15.2 & 14.8 & 11.6 & 9.6 & 7.7 & 30.0 & 11.1 \\
\hline
\end{tabular}

Source: Higher Education in India: Twelfth Five Year Plan (2012-2017) and beyond

Table 4 shows the Gross Attendance ratio (GAR) of higher education in gender, community wise and urban and rural areas. In the year 2007-08, gender wise GAR is $19 \%$ for male and $15.2 \%$ for females. Share of community wise shows that OBCs hold $14.8 \%$, SCs $11.6 \%, 7.7 \%$ for STs and $9.6 \%$ for Muslims. Urban and rural area constitutes $30 \%$ and $11.1 \%$ respectively during $2007-08$.

Table 5Number of Universities, Colleges, Students and Teaching staff Enrolment during last four decades

\begin{tabular}{|l|r|r|l|c|}
\hline Year & \multicolumn{1}{|l|}{ Universities } & Colleges & $\begin{array}{l}\text { Students } \\
\text { enrolment } \\
\text { (in millions) }\end{array}$ & $\begin{array}{l}\text { Teaching staff } \\
\text { enrolment } \\
\text { (in millions) }\end{array}$ \\
\hline $1970-71$ & 103 & 3604 & 2 & NA \\
\hline $1980-81$ & 133 & 4722 & 2.8 & 0.19 \\
\hline $1990-91$ & 190 & 7346 & 4.9 & 0.26 \\
\hline $2000-01$ & 256 & 12806 & 8.4 & 0.41 \\
\hline $2006-07$ & 387 & 21170 & 16.6 & 0.82 \\
\hline $2011-12$ & 659 & 33023 & 25.9 & NA \\
\hline CAGR & 4.6 & 5.6 & 6.4 & 4.9 \\
\hline
\end{tabular}

Source: Higher Education in India: Twelfth Five Year Plan (2012-2017) and beyond

Table 5 depicts the number of Universities, Colleges, Students and Teaching staff enrollment during last four decades. In India, the number of Universities has grown more than six times in the last four decades. It has more than 33,000 colleges with one-third of the colleges having been setup in the last five years. Students' enrolment in higher education in the year 1970-71 was 2 million and 25.9 million in the year 2011-12, which 
has grown 12 times in the last four decades. The teaching staff enrollment strength was 0.19 million in the year 1980-81 and it was 0.82 million in the year 2006-07, which has grown only 4 times during last three decades.

\section{Few Current Issues}

- On November 28, 2013 Bangalore, in an All India Conference of higher education ministers on Rashtriya Uchchatar Shiksha Abhiyan (RUSA), Higher Education Secretary in the HRD Ministry Ashok Thakur said today. "We will be creating about 278 new universities and 388 new colleges. Some of these colleges will be motivated to become universities", he said at an all India conference of higher education ministers on Rashtriya Uchchatar Shiksha Abhiyan (RUSA), a flagship scheme of the UPA government.

- October 2, 2013Bangalore, Industry captain and philanthropist Azim Premji has called upon the Government and other stakeholders to invest more resources to improve the state of education in the country. "These 12 years (of Azim Premji Foundation) have taught us that transforming education is very complex."And given the diversity of our country, compounded by issues of socio-economic deprivation and on-the-ground realities, it is inevitably going to be a slow and arduous process,"...

- $\quad$ September 6, 2013, NEW DELHI: Higher education system in the country is faced with the problems of poor quality of curriculum, instruction, teacher quality and research, a Parliamentary Panel said today. The panel chaired by Francisco Sardinha also said that India's Gross Enrolment Ratio (GER) in higher education is well below global standards.

\section{Findings}

During eleventh plan (2007-12) India achieved a GER of $17.9 \%$ up from $12.3 \%$ at the beginning of the plan period. India ranks second in the world in terms of enrollment of students in higher education institutions. But, India's GER of $17.9 \%$ (2012) was much below the world average of $27 \%$, as well as that of other emerging countries such as China (26\%), USA (95\%) and Brazil (36\%) in 2010.The students' enrollment in higher education has grown six times in the last 30 years; the faculty strength has grown only four times, resulting in shortage of faculty and high student-teacher Ratios. General courses account for the largest share of enrollment but enrolment in professional courses (such as engineering and medicine) has witnessed a higher growth in the last five years. There is wide disparity in the Gross Attendance ratio (GAR) of higher education in urban and rural areas, and gender and community-wise, Urban-rural divide $30 \%$ in urban areas vs $11.1 \%$ in rural areas, there is significant gender disparity dividing $19 \%$ for male and $15.2 \%$ for female and differences also across communities $-14.8 \%$ for OBCs, $11.6 \%$ for SCs, $7.7 \%$ for STs and $9.6 \%$ for Muslims.

\section{Conclusion}

However, in spite of the significant progress made during the past few years, India's higher education sector is still in danger with several challenges with its relatively low Gross enrollment ratio (GER). According to the report on Higher Education in India: Twelfth Five Year Plan (2012-2017) and beyond, the India's higher education system faces challenges on three fronts - expansion, equity and excellence. Higher education institutions should focus on holistic development of an individual and, therefore, focus on development of multiple intelligence rather than merely linguistic and logical intelligence of an individual. All universities and colleges should be given the autonomy to start self-financing courses particularly in new and emerging areas where job opportunities exist subject to the overall framework provided by their funding and regulatory bodies.

\section{References}

[1] P. K. Manoharan Higher Education: A. P.H. Publishing Corporation, New Delhi,

[2] SanatKaulHigher Education in India: Seizing the Opportunity, 2006.

[3] AbhayPethe, Higher Education: Governance is the key!

[4] Indian Higher Education - The defining years, KPMG-Edge forum report, 2012

[5] Report on HIGHER EDUCATION IN INDIA Strategies and Schemes during Eleventh Plan Period(2007-2012) for Universities and Colleges 